\title{
Pathogenicity and susceptibility/resistance reaction of feijoa (Feijoa sellowiana) cultivars to anthracnose
}

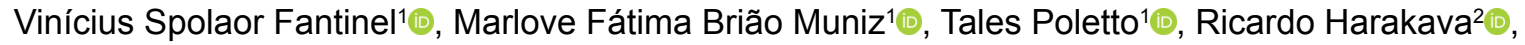 \\ Marlise Nara Ciotta $^{3} \oplus$, Lucas Graciolli Savian ${ }^{1}$, Renata Fontana Favaretto ${ }^{1} \oplus$, Jaqueline Raquel Tomm Krahn ${ }^{1} \oplus$

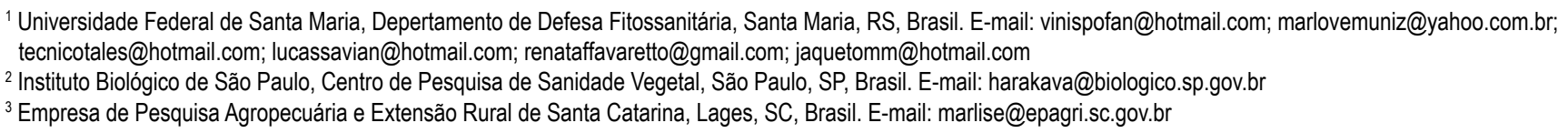

ABSTRACT: The objective of this study was to determine the pathogenicity of Colletotrichum theobromicola, $C$. siamense and C. fructicola, C. nympahaeae and C. pseudoacutatum to feijoa, as well as to study the susceptibility/resistance reaction of the commercial cultivars "Alcântara", "Helena", "Mattos", and "Nonante" to anthracnose. For that, spore suspensions (106 spores $\mathrm{mL}^{-1}$ ) of the Colletotrichum isolates were prepared from colonies grown for seven days in Mathur medium. Ten fruits at the medium stage of development of each cultivar were used for the inoculation of each isolate. First the fruits were disinfested superficially, then they were accommodated in polypropylene trays and the suspension was applied in three places on the fruit's surface, without injury. All those species are pathogenic to feijoa, as they reproduced the original symptoms of anthracnose. The susceptibility of cvs. "Helena" and "Nonante" were influenced by the specific variability of the pathogen. The cv. "Alcântara" is susceptible and cv. "Mattos" is resistant to all tested Colletotrichum species. Thus, cv. "Mattos" is the most suitable feijoa cultivar to reduce anthracnose levels in orchards in a conventional, integrated or organic cultivation system.

Key words: breeding program; Colletotrichum spp.; inoculation

\section{Patogenicidade e reação de suscetibilidade/resistência de cultivares de goiabeira-serrana (Feijoa sellowiana) à antracnose}

RESUMO: Objetivou-se determinar a patogenicidade de Colletotrichum theobromicola, C. siamense e C. fructicola, C. nympahaeae e C. pseudoacutatum, a goiabeira-serrana, bem como estudar a reação de suscetibilidade/resistência das cultivares comerciais "Alcântara", "Helena", "Mattos", e "Nonante" à antracnose. Para tanto, a partir de colônias com sete dias de crescimento em meio Mathur, foram preparadas suspensões de esporos (106 esporos $\mathrm{mL}^{-1}$ ) dos isolados de Colletotrichum. Foram utilizados 10 frutos para cada cultivar os quais foram desinfestados superficialmente, em seguida foram acomodados em bandejas de polipropileno e a suspensão foi aplicada em três locais sobre a superfície do fruto, sem ferimento. As espécies são patogênicas à goiabeira-serrana, pois reproduziram os sintomas originais da antracnose. A suscetibilidade das cvs. "Helena" e "Nonante" foi influenciada pela variabilidade específica do patógeno. A cv. "Alcântara" é suscetível e a cv. "Mattos" é resistente à todas as espécies de Colletotrichum testadas. Dessa forma, a cv. "Mattos" é a cultivar de goiabeira-serrana mais indicada para reduzir os níveis de antracnose nos pomares em sistema de cultivo convencional, integrado ou orgânico.

Palavras-chave: programa de melhoramento; Colletotrichum spp.; inoculação 


\section{Introduction}

Feijoa [Feijoa sellowiana (O. Berg) O. Berg] is a fruit species of the Myrtaceae family, native to the southern Brazilian highlands and northeastern Uruguay, also known as, mountain-guava or feijoa. In the southern region of Brazil, this species presents excellent adaptability to cold weather, occurring more frequently in areas with altitudes higher than 900 m (Wagner et al., 2020).

The fruit of feijoa is classified as pseudofruit if the pome type, usually oblong with a green shell of smooth or rough texture. The pulp is light in color, while the taste and aroma of the fruit have striking characteristics (Amarante et al., 2019). The fruit can be consumed fresh or as juices, jellies, and liqueurs, among others. Fruits have also nutraceutical, antibacterial and antioxidant properties, likely due to the presence of phenolic compounds, such as phenolics, tannins and flavonoids, included in the latter as anthocyanins, in both pulp and shell (Amarante et al., 2017). Additionally, feijoa has great potential for ornamental use, landscaping, and the recovery of degraded areas (Donazollo, 2015).

Although the species has considerable economic potential, commercial plantations are rare in Brazil mainly due to the susceptibility of this species to pests and diseases (Araújo \& Pinto, 2018).

According to Araújo \& Pinto (2018), considering the phytosanitary aspect, anthracnose is the main disease that affects the crop. It is caused by fungi of the genus Colletotrichum that can damage up to $100 \%$ of young or near ripening fruits (Araújo \& Pinto, 2018). Recently, Fantinel et al. (2017) identified $C$. siamense causing well-defined dark spots of irregular shape in feijoa. These spots increase in size, become depressed and coalesced, leading to rotting of the fruits and, consequently, reducing productivity in orchards.

For viable commercial cultivation of this species, it is important to select cultivars with superior characteristics in terms of productivity, production stability and fruit quality. With this intent, researchers from the Santa Catarina Agricultural Research and Rural Extension Company (Epagri), Federal University of Santa Catarina (UFSC), and University of the State of Santa Catarina (UDESC) launched four high potential feijoa cultivars: "Alcântara", "Helena", "Mattos", and "Nonante" (Ducroquet et al., 2007; Ducroquet et al., 2008).

Regarding the resistance to anthracnose, these cultivars do not present significant differences to wild specimens, being eventually necessary the use of control measures for this disease in the orchards. However, the quantification of the disease is fundamental for the correct interpretation of control studies. In general, the most used measures to quantify plant diseases are incidence and severity. Incidence is defined as the percentage (frequency) of contaminated plants or parts of contaminated plants in a sample or population, while severity is defined as the percentage of area or volume of tissue covered by symptoms (Amorim et al., 2018).

The main form of anthracnose management in Brazilian orchards has been the integrated disease management, with the implantation of orchards in suitable areas with shading, and drainage, using spacings that allow insolation and aeration of plants, besides that, the pruning, balanced fertilizers, reducing the initial inoculum through such as evasion, exclusion, eradication and the use of resistant cultivars (Fantinel, 2020).

The use of genetic resistance is considered the preferred method to control diseases because it is a strategy of greater durability and does not increase production costs (Singh et al., 2015). Thus, the development of new cultivars with similar phenological characteristics, but with different resistance genes, may facilitate the use of genetic control in feijoa orchards.

The development of plant pathogen-resistant materials requires reliable disease assessment and selection techniques. Most studies evaluating plant germplasm are conducted in the field with a history of the disease (Walker et al. 2018). These studies may yield inconsistent results, as several factors inherent to the pathosystem may vary between locations and between harvests (Ishikawa et al., 2018). To minimize this irregularity, tests under controlled conditions in greenhouse or growth chambers are indicated, with standardization of environmental conditions and inoculation techniques.

According to a recent study using multigenic molecular analysis (Fantinel, 2020) it was possible to accurately identify Colletotrichum species associated with anthracnose in feijoa. This identification, at stricto sensus level (defined taxon), defined the isolates as belonging to two species complexes: the Colletotrichum gloeosporioides complex (C. theobromicola, $C$. siamense, and $C$. fructicola) and the Colletotrichum acutatum complex (C. nymphaeae), as well as C. pseudoacutatum, a species that is not associated with any complex.

Thus, the objective of this work was to test the pathogenicity of isolates of Colletotrichum spp. and to evaluate the susceptibility/resistance reaction of the main Brazilian commercial cultivars of feijoa to anthracnose.

\section{Materials and Methods}

The pathogenicity test of Colletotrichum spp. associated with anthracnose symptoms in feijoa was conducted concomitantly with the evaluation of the susceptibility/ resistance reaction of the commercial cultivars "Alcântara", "Helena", "Mattos", and "Nonante" to anthracnose.

Between February and March of the years 2016 and 2017, fruits with anthracnose symptoms caused by Colletotrichum spp. were collected in feijoa orchards in the states of Rio Grande do Sul, Santa Catarina, and Paraná in Brazil and the Department of Salto, in Uruguay. The isolates used in the present study were selected based on the phylogenetic trees constructed with the thirteen isolates of Colletotrichum by sequencing the ITS, Actin and $\beta$-tubulin regions (Table 1 ). In addition to these isolates, the species $C$. siamense previously identified causing anthracnose in feijoa (Fantinel et al., 2017) was included in this study. 
In this way, species from all Colletotrichum spp. complexes associated with anthracnose in feijoa in its naturally occurring area were selected: $C$. gloeosporioides complex [C. siamense (1 isolated), C. fructicola (1 isolated) and C. theobromicola (5 isolated)] and C. acutatum complex [C. nymphaeae (6 isolates)], as well as $C$. pseudoacutatum, a species that is not associated with any complex.

To perform the pathogenicity test and to evaluate the susceptibility/resistance reaction of the feijoa cultivars to anthracnose, healthy ripe fruits of cultivars "Alcântara", "Helena", "Mattos", and "Nonante" were collected, without apparent symptoms of anthracnose or the attack of other phytopathogens. The fruits were collected from the orchard of the Active Germplasm Bank maintained by EPAGRI in the municipality of São Joaquim/SC (28 $17^{\prime} 25^{\prime \prime}$, 4956'56"W, $1415 \mathrm{~m}$ of altitude). The fruits were disinfested for $30 \mathrm{~s}$ with $70 \%$ ethanol, $1 \%$ sodium hypochlorite and washed three times in sterile distilled water. Subsequently, they were placed over filter paper to remove the water excess at room temperature. They were then placed in polypropylene trays $(33 \times 21.8 \times 10.3$ $\mathrm{cm}$ ) over two sheets of filter paper.

Sporulation of Colletotrichum species was obtained through fungi cultivation in Mathur medium for 14 days in an incubation chamber at $25^{\circ} \mathrm{C}$ and $12 \mathrm{~h}$ of photoperiod.
Subsequently, with the aid of a Drigalski handle, the fungal mycelium was scraped from the surface of the medium and transferred to new Petri plates. The spores' suspension was obtained from each isolate by adding $10 \mathrm{~mL}$ of distilled and sterilized water per plate containing each Colletotrichum species. The suspension was filtered through a double layer of gauze and the spore concentration was counted using the Neubauer chamber. The spore concentration of the suspension was adjusted to $1 \times 10^{6}$ spores $\mathrm{mL}^{-1}$ (Lopes, 2013).

According to Degenhardt et al. (2007), considering the repeatability coefficients, ten feijoa fruits per cultivar are sufficient to express heritability values, based on their genetic and phenotypic variability. Thus, for the application of spore suspension, ten fruits per isolate were used for each cultivar. Each repetition consisted of one fruit.

The spore suspension was applied according to the methodology proposed by Lopes (2013) with modifications. Each fruit was inoculated with $100 \mu \mathrm{L}$ of the suspension, divided into three drops, distributed separately over the exocarp. In the control treatment, the inoculation was performed only with distilled and sterile water. Afterward, the fruits were incubated at $25^{\circ} \mathrm{C}$ and $12 \mathrm{~h}$ photoperiod, and every two days the filter papers were rewetted. Wet chamber conditions are necessary for the inoculum to have favorable

Table 1. Isolates of Colletotrichum spp. obtained from fruits with symptoms of anthracnose in southern Brazil and Uruguay, selected for the tests of pathogenicity and cultivars response.

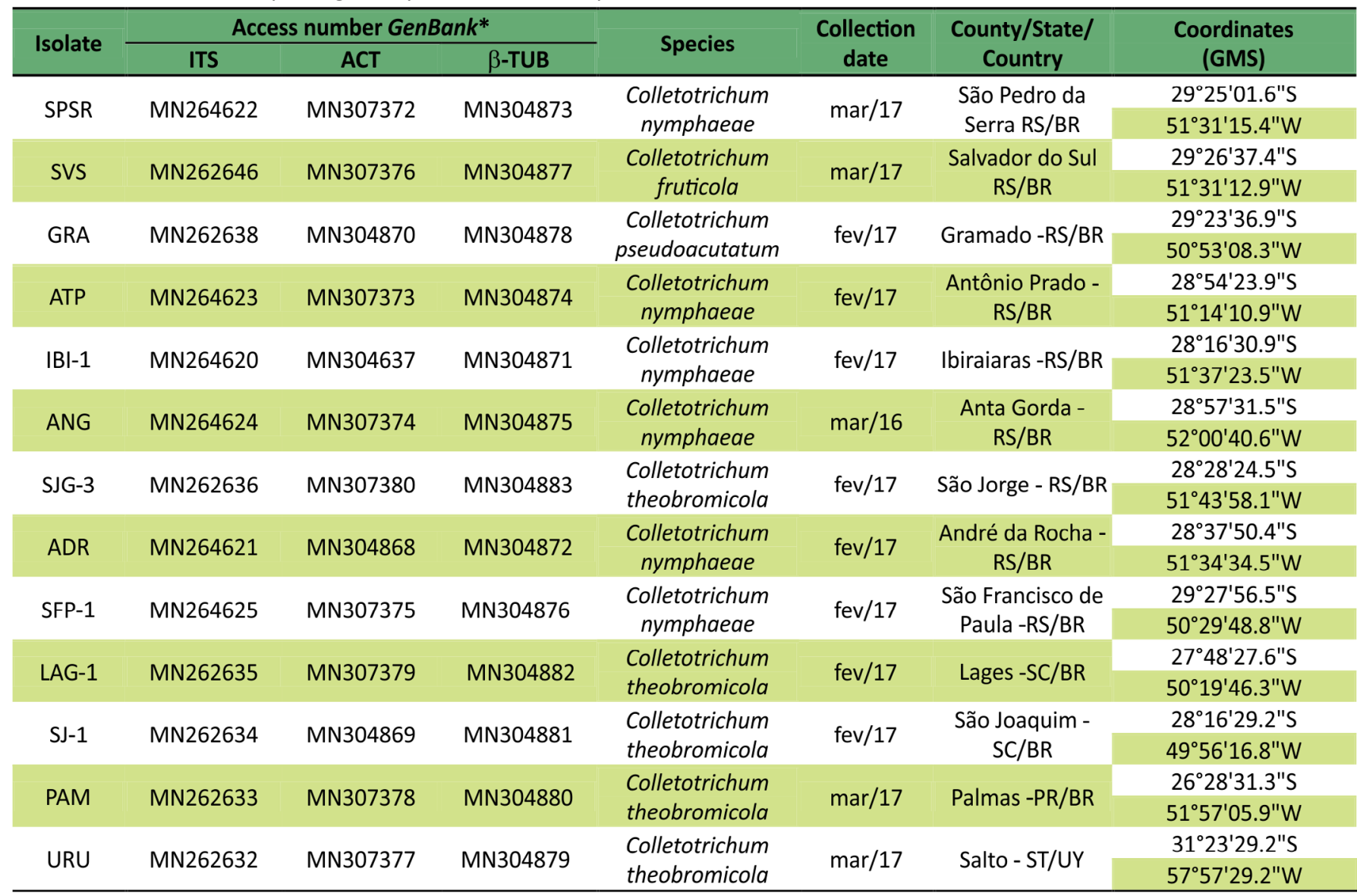

${ }^{1}$ Identification of the Colletotrichum species through the sequencing of the ITS, Actin (ACT) e $\beta$-tubulin ( $\beta$-TUB) regions

${ }^{2}$ RS = Rio Grande do Sul State, SC = Santa Catarina State, PR = Paraná State, BR = Brazil, UY = Uruguay 
environmental conditions to initiate the germination and penetration processes in the host tissues.

The anthracnose incidence was visually quantified 20 days after spore suspension inoculation using a stereoscopic microscope (Lopes, 2013). If the disease symptom was observed in at least one of the drops deposited on the fruit, the incidence was quantified as positive or, in the absence of disease symptoms, as negative, for each fruit (repetition).

The severity was observed in each fruit, where the drops of spore suspension were applied, counting the number of lesions. A diagrammatic scale was used attributing scores from 1 to 4 , where $1=0 \%$ (without symptoms); $2=33.3 \%$ (one drop with symptom); $3=66.6 \%$ (two drops with symptom); 4 $=100 \%$ (three drops with symptom). Cultivars that received average grades between 1 and 2 were considered resistant, cultivars that received grade averages between 2 and 3 were considered moderately resistant and those scoring above 3 were considered susceptible. To confirm pathogenicity, after evaluations, the pathogens were reisolated, completing the Koch's postulates.

The tests of pathogenicity and reaction of cultivars were carried out simultaneously in a completely randomized design in a factorial scheme composed of two factors (5 species of Colletotrichum x 4 feijoa's cultivars). Ten replicates per isolate per cultivar were used, and each fruit represented a sample unit. Data were subjected to analysis of variance and comparison tests were performed through the Tukey test at $5 \%$ probability of error, using the statistical program SISVAR version 5.3 (Ferreira, 2011).

\section{Results and Discussion}

The first anthracnose symptoms in feijoa fruits were observed on the fourth day after the inoculation of $C$. nymphaeae, C. siamense, C. fructicola, C. theobromicola, and $C$. pseudoacutatum spore suspension. All isolates were pathogenic to cultivars "Alcântara", "Helena", "Mattos", and "Nonante". The lesions observed in the fruits inoculated with C. fructicola began with small dark punctuation at the pathogen inoculation site, which evolved in size, coalesced and formed larger areas of necrotic tissue (Figure 1).

The coloration of the conidial mass varied according to the causal agent of anthracnose. In general, the lesions with salmon and orange conidial mass were produced by isolates of the $C$. acutatum and $C$. gloeosporioides complexes respectively, while fruits inoculated with $C$. pseudoacutatum presented dark lesions.

The symptoms presented correspond to the original ones, typical of the disease when observed in the field. Fruits that were inoculated with sterile water (control) showed no lesion, sporulation, and conidial mass. To complete Koch's postulates, after the onset of symptoms, the pathogen was reisolated in Mathur medium and its structures were visualized with the aid of a stereoscopic and optical microscope. Thus, it can be stated that the lesions present in fruits inoculated with Colletotrichum spp. spores were obtained from the bioassay.

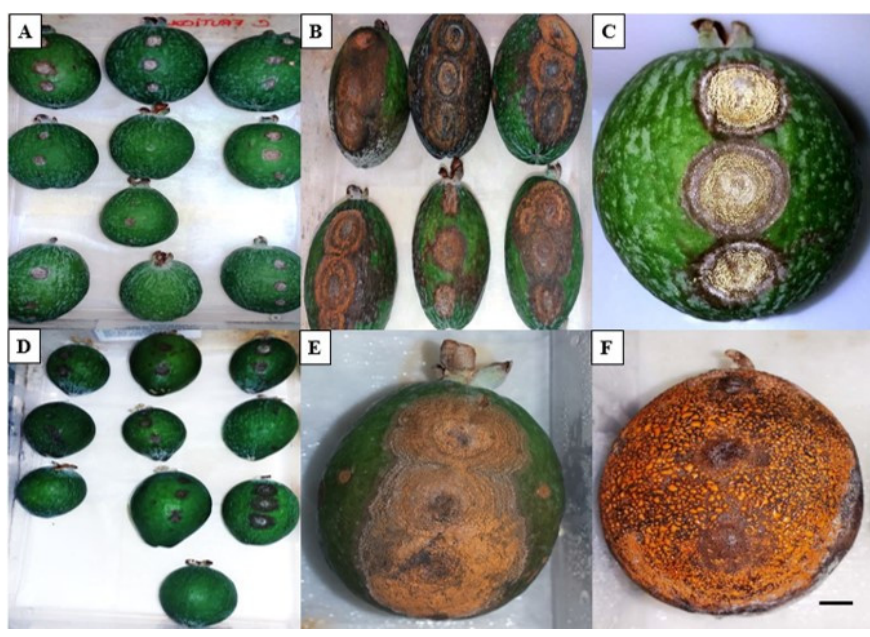

Figure 1. Symptoms of anthracnose in feijoa fruits after artificial inoculation of C. fructicola isolates. A. Fruits of the "Mattos" cultivar on the fourth day after $C$. fructicola inoculation. B. Fruits of cultivar "Mattos" on the 15th day after C. fructicola inoculation. C. Fruits of the cultivar "Mattos" on the twentieth day after inoculation. D. Fruits of the cultivar "Helena" on the fourth day after inoculation. E. Coalescing lesions caused by C. fructicola in cultivar "Helena" on the 15th day after inoculation. F. Fruit of cultivar "Helena" on the twentieth day after inoculation with the fully coalesced lesions caused by $C$. fructicola. The orange color (mucilage) shows the presence of the fungus spores. Bar $=2.0 \mathrm{~cm}$

Colletotrichum nymphaeae showed $100 \%$ incidence in all cultivars, revealing the ability to infect fruit tissue in all replications. $C$. siamense and $C$. fructicola had the highest incidence (100\%) in cultivars "Alcântara", "Helena", and "Mattos". In the cultivar "Nonante", C. siamense and $C$. fructicola presented 90 and $80 \%$ of incidence, respectively. $C$. theobromicola and $C$. pseudoacutatum presented the lowest incidences (60 and 70\% respectively) in the cultivar "Mattos" and maximum incidence in "Helena" and "Nonante" (Table 2).

It is important to highlight that the classical taxonomy enabled so far identifying the causal agents of anthracnose in feijoa only at the broad sense level (species complexes). Hellwig \& Ueno (2009) found a high incidence of feijoa plants with branch dryness and fruit rot in Brazil. It was likely caused by Colletotrichum gloeoesporioides, making the economic production of this fruit impracticable, since in some plants practically all branches were compromised. Similarly, Lopes (2013) identified, through morphological characteristics, isolates of Colletotrichum spp. associated with fruits of feijoa. In New Zealand, where the species is widely cultivated, Lardner et al. (1999) identified Colletotrichum acutatum causing anthracnose symptoms in feijoa plants.

Recently, multigenic molecular analysis allowed to more precisely identify causal agents at the stricto sensus level (defined taxon). Fantinel et al. (2017) published the first report of $C$. siamense causing typical anthracnose symptoms in feijoa fruits in Brazil. This study is relevant as it identified the pathogen through three gene regions (TEF1- $\alpha, \beta$-tubulin, and 
Actin), ensuring the identity of the causal agent. In a more recent study, Camele et al. (2018) reported for the first time the fungus Colletotrichum acutatum causing anthracnose in feijoa fruits in the provinces of Bari and Matera in Italy. In this study, the pathogen was also identified through multigenic analysis.

According to Baroncelli et al. (2015), species of the genus Colletotrichum are also reported as causal agents of anthracnose in other hosts causing serious crop losses in Brazil and other countries.

In the present study, the species $C$. nymphaeae, $C$. siamense, C. fructicola, C. theobromicola, and C. pseudoacutatum were pathogenic to the cultivars "Alcântara", "Helena", "Mattos" and "Nonante", and differences in aggressiveness were found concerning the same cultivar ("Helena" and "Nonante") as well as when the four cultivars were compared (Table 2).

The five species of Colletotrichum inoculated in cultivars "Alcântara" and "Mattos" differed from the control but did not show significant differences between them. According to the grade scale used, the average ranged from 3.0 to 4.0 (degree of disease severity from 66.33 to $100 \%)$. In cultivar "Helena" C. siamense differed significantly from other species with a grade point average of 3.5. C. nymphaeae presented the highest severity scores for cultivar "Nonante", being therefore the most aggressive for this cultivar.

According to Amorim et al. (2018), severity denotes the percentage of the area or /volume of the plant tissue covered by symptoms. Another variable that quantifies the degree of disease manifestation is incidence, which is the percentage of contaminated plants in a sample or population. The assessment of disease severity therefore reflects the degree of host susceptibility and pathogen aggressiveness.

The detection of more aggressive isolates is important because they can be used for selection and better discernment between resistant and susceptible genotypes.

For the cultivar "Mattos", C. nymphaeae presented lower aggressiveness (average grade of 1.3) with significant differences concerning cultivars "Alcântara" (4.0), "Helena" (2.3), and "Nonante" (4.0). Considering $C$. nymphaeae as a causal agent of anthracnose, cultivars "Alcântara", "Helena", and "Nonante" are more susceptible to the disease when compared to "Mattos".

The species belonging to the $C$. gloeosporioides complex (C. siamense, C. fructicola, and C. theobromicola) provided similar results regarding the average severity grades. This grade, in turn, differed significantly from the others only in cultivar "Mattos" which makes the cultivar resistant to disease when caused by pathogens of this complex.

Cultivar "Mattos" had the lowest average severity grade (1.8) for C. pseudoacutatum, a species that does not belong to any species complex, differing significantly from the others. Cultivar "Alcântara" had the highest grade, indicating that this cultivar is susceptible to anthracnose, considering $C$. pseudoacutatum as causal agent of the disease.

"Alcântara" was considered as an anthracnose susceptible cultivar, as it presented all average grades of severity greater than or equal to 3. The susceptibility of cultivars "Helena" and "Nonante" to anthracnose vary according to the species of Colletotrichum. These cultivars were susceptible to anthracnose caused by $C$. siamense and C. nymphaeae species, respectively, and showed moderate resistance to the others. The only cultivar that showed resistance to anthracnose was the "Mattos" which presented average severity scores between 1 and 2 for all Colletotrichum species.

According to Amarante et al. (2019), feijoa fruits show great diversity in size and shell thickness, among other factors. Thus, some inherent characteristics of cultivar "Mattos" may be related to the resistance of this cultivar to anthracnose. According to Ducroquet et al. (2008), the fruits of cultivar "Mattos" have relatively thick outer bark or parenchyma and this may hinder the pathogen's infection mechanism. Among the cell wall modifications that have the function of protecting plants from their pathogenic agents, which can be mentioned: cutin, carbohydrates, gels and tylos, ligine.

Table 2. Mean values of incidence and severity grades (\%) of anthracnose induced by artificial inoculation of Colletotrichum spp. in feijoa fruits in the cultivars "Alcântara", "Helena", "Mattos" and "Nonante".

\begin{tabular}{|c|c|c|c|c|}
\hline \multirow{2}{*}{ Species/Isolates } & \multicolumn{4}{|c|}{ Cultivars } \\
\hline & "Alcântara" & "Helena" & "Mattos" & "Nonante" \\
\hline & \multicolumn{4}{|c|}{ Incidence (\%) } \\
\hline Colletotrichum nymphaeae (ADR, ANG, SFP-1, SPSR, IBI-1, ATP)* & 100 & 100 & 100 & 100 \\
\hline Colletotrichum siamense (SPS) & 100 & 100 & 100 & 90 \\
\hline Colletotrichum fructicola (SVS) & 100 & 100 & 100 & 80 \\
\hline Colletotrichum theobromicola (PAM, SJ-1, URU, LAG-1, SJG-3) & 100 & 100 & 60 & 100 \\
\hline Testemunha & \multicolumn{4}{|c|}{ Severity notes ( 0 a 4 ) } \\
\hline Colletotrichum nymphaeae (ADR, ANG, SFP-1, SPSR, IBI-1, ATP) & $4.0 * * \mathrm{Cb}^{* * *}$ & $2.3 \mathrm{Bb}$ & $1.3 \mathrm{Ab}$ & $4.0 \mathrm{Cc}$ \\
\hline Colletotrichum siamense (SPS) & $3.3 \mathrm{Bb}$ & $3.5 \mathrm{Bc}$ & $1.5 \mathrm{Ab}$ & $2.9 \mathrm{Bb}$ \\
\hline Colletotrichum fructicola (SVS) & $3.0 \mathrm{Bb}$ & $2.6 \mathrm{Bb}$ & $1.6 \mathrm{Ab}$ & $2.2 \mathrm{Bb}$ \\
\hline Colletotrichum theobromicola (PAM, SJ-1, URU, LAG-1, SJG-3) & $3.1 \mathrm{Bb}$ & $2.8 \mathrm{Bb}$ & $1.2 \mathrm{Ab}$ & $2.1 \mathrm{Bb}$ \\
\hline
\end{tabular}

* All isolates were tested separately; ${ }^{* *}$ Severity Notes 1 = 0 injuries; $2=1$ lesion; $3=2$ lesions; $4=3$ lesions; ***Means followed by different uppercase letters in the row and lowercase letters in the column differ statistically from each other by Tukey's test at $5 \%$ probability of error. C.V. (\%) $=$ coefficient of variation 
The cutin acts as a chemical and physical barrier in the germination and penetration of fungi inside the cells. Cutin thickness was correlated with levels of plant resistance to the fungus that penetrates directly into the tissues. In susceptible hosts, the secondary wall thickness is usually deficient or poorly developed (De Lima, 2016).

Another important factor to note is that this cultivar has specific endophytic fungal microbiota associated with fruits. The species Trichoderma harzianum, Trichoderma hamatum, Clonostachys rosea, and Clonostachys rhizophaga occur exclusively in this cultivar (Fantinel, 2020).

Due to the above characteristics, cultivar "Mattos" is the most suitable for reducing anthracnose levels in orchards in conventional, integrated or organic cultivation systems.

In general, there is variation in susceptibility of cultivars of feijoa to anthracnose and species included in the $C$. acutatum and $C$. gloeosporioides complexes and $C$. pseudoacutatum species show different degrees of aggressiveness.

Pathogenic variability is a very important parameter in the characterization of Colletotrichum isolates since it provides useful information to breeding programs contributing to the identification of potential gene donors. Considering this fact, several studies have been developed, such as those by Araújo et al. (2016), who studied isolates of C. gloeosporioides obtained from mango (Mangifera indica), guava (Psidium guajava) and papaya (Carica papaya) concerning the morphological traits, virulence, and aggressiveness, evidencing pathogenic variability among isolates.

Different studies have been conducted in recent years based on the search for genotypes resistant to the main crop diseases. However, there is no detailed information on the behavior of the genotypes constituting the active germplasm bank of EPAGRI - São Joaquim (SC) (Mosquera et al., 2018). According to Camargo (2018), these studies are extremely important as genetic resistance is considered one of the most efficient, low cost, and clean strategies for the management of plant diseases.

According to Araújo \& Pinto (2018), there are no commercial cultivars of feijoa immune to anthracnose. Ducroquet et al. (2008) described cultivar "Nonante" as a cultivar that requires anthracnose control measures in fruits, while "Alcântara", which is originated from essentially native material from seed collection, and "Helena", have good anthracnose tolerance (Ducroquet et al., 2007). However, in a study conducted by Araújo \& Pinto (2018), “Helena” presented higher susceptibility to anthracnose together with "Alcântara" and "Mattos" and the most resistant cultivar was "Nonante". Although the Colletotrichum species were not molecularly characterized in those studies, the results contrast with those of the present work since, in this study, cultivars "Helena" and "Nonante" showed variation in susceptibility to anthracnose, according to the species of the causal agent.

According to Donazzolo et al. (2020), the genetic diversity of feijoa is distributed from Paraná State in Brazil to Uruguay, with special consideration to the region of the Rio Grande do Sul highlands, where it was reported occurring at lower altitudes than in Santa Catarina. This wide distribution may include the presence of different alleles and allelic associations, indispensable for the development of cultivars more adapted to different environments of the altitude areas for which the studies has been developed, especially concerning anthracnose resistance. It is important to note that in the present study, isolates were collected in the naturally occurring area of feijoa, with a large sampling of Colletotrichum spp.

As a next step, we suggest the development of breeding studies searching for genotypes of feijoa with high resistance to the Colletotrichum species evaluated in the present work, considering that its manifestation is a huge problem in orchards in Brazil.

\section{Conclusions}

Colletotrichum nymphaeae, C. siamense, C. fructicola, $C$. theobromicola, and $C$. pseudoacutatum are pathogenic to feijoa, causing anthracnose in fruits.

The cultivar "Alcântara" is susceptible to anthracnose caused by the Colletotrichum species tested, while the susceptibility reaction of cultivars "Helena" and "Nonante" vary according to the pathogen species.

The cultivar "Mattos" is resistant to anthracnose caused by the Colletotrichum species tested.

\section{Acknowledgments}

Authors thank Coordination for the Improvement of Higher Education Personnel (Capes) by the scholarship granted (Finance Code 001) and CNPq by the Research Productivity Grant (PQ) for Marlove Fátima Brião Muniz.

\section{Literature Cited}

Amarante, C.V.T., Souza, A.G., Steffens, C.A., Beninca, T.D.T. Centesimal and mineral composition of the fruit in Brazilian genotypes of feijoa (Acca sellowiana). Revista Brasileira de Fruticultura, v. 41 n. 6, e487, 2019. https://doi.org/10.1590/0100-29452019487.

Amarante, C.V.T., Souza, A.G., Steffens, C.A., Beninca, T.D.T. Phenolic content and antioxidant activity of fruit of Brazilian genotypes of feijoa. Pesquisa Agropecuária Brasileira, v.52, n.12. pp.1223-1230, 2017. https://doi.org/10.1590/s0100-204×2017001200011.

Amorim, L.; Rezende, J.A.M.; Bergamin Filho, A. Manual de fitopatologia: princípios e conceitos. Piracicaba: Ceres, 2018. v. $1,573 p$.

Araújo, L.; Pinto, F.A.M.F. Principais doenças e seu controle. In: Ciotta, M.N.; Arioli, C.J.; Pinto, F.A.M.F.; Santos, K.; Araújo, L.; Pasa, M.S. (Orgs.). A cultura da goiabeira-serrana. Florianópolis: Epagri, 2018. p.147-166.

Araújo, N.A.F.; Vieira J.D.M.; Moura M.D.R.; Pessoa W.R.L.S.; Barguil, B.M. Pathogenicity and aggressiveness of Colletotrichum gloeosporioides isolates in ornamental pepper. Pesquisa Agropecuária Tropical, v.46, n.3, p.321-326, 2016. https://doi. org/10.1590/1983-40632016v4641483. 
Baroncelli, R.; Zapparata, A.; Sarrocco, S.; Sukno, S.A.; Lane, C.R.; Thon, M.R.; Vannacci, G.; Holub, E.; Sreenivasaprasad, S. Molecular diversity of anthracnose pathogen populations associated with UK strawberry production suggests multiple introductions of three different Colletotrichum species. PLoS One, v.10, n.6, e0129140, 2015. https://doi.org/10.1371/journal.pone.0129140.

Camargo, L.E.A. Controle genético. In: Amorim, L.; Rezende, J.A.M.; Bergamin Filho, A. (Eds.). Manual de fitopatologia: princípios e conceitos. 5.ed. São Paulo: Agronômica Ceres, 2018. v.1, cap. 15, p.229-238.

Camele, I.; Mang, S.M.; Elshafie, H.S.; Frisullo, S. First report of Colletotrichum acutatum causing anthracnose in Feijoa sellowiana in Italy. Plant Disease, v.102, n.9, p.1850, 2018. https://doi.org/10.1094/PDIS-01-18-0183-PDN.

De Lemos, A.L.; Mauss, C.J.; Santana, R.C. Characterization of natural fibers: wood, sugarcane and babassu for use in biocomposites. Cellulose Chemistry and Technology, v.51, n. 7-8, p.711-718, 2017. http://www.cellulosechemtechnol.ro/pdf/ CCT7-8(2017)/p.711-718.pdf. 05 May. 2020.

Degenhardt, J.; Ducroquet, J.P.; Reis, M.S.; Guerra, M.P.; Nodari, R.O. Goiabeira Serrana: estimativa de variabilidade para características de frutos com base no coeficiente de repetibilidade. Pelotas: Embrapa Clima Temperado, 2007. 18p. (Boletim de Pesquisa e Desenvolvimento, 51).

Donazzolo, J., Ornellas, T.S., Bizzocchi, L., Vilperte, V., and Nodari, R.O. $\mathrm{O}$ armazenamento refrigerado prolonga a viabilidade de sementes de goiabeira-serrana. Revista Brasileira de Fruticultura. v.37, n.3, p.748-754, 2015. https://doi.org/10.1590/0100-2945-179/14.

Donazzolo, J.; Stefenon, V.M.; Guerra, M.P.; Nodari, R.O. On farm management of Acca sellowiana (Myrtaceae) as a strategy for conservation of species genetic diversity. Scientia Horticulturae, v.259, e108826, 2020. https://doi.org/10.1016/j. scienta.2019.108826.

Ducroquet, J.P.H.J.; Nunes, E.C.; Guerra, M.P.; Nodari, R.O. Novas cultivares brasileiras de goiabeira serrana: SCS 414-Mattos e SCS 415-Nonante. Agropecuária Catarinense, v.21, n.2, p.77-80, 2008.

Ducroquet, J.P.H.J.; Santos, K.L.; Andrade, E.R.; Boneti, J.I.S.; Bonin, V.; Nodari, R.O. As primeiras cultivares brasileiras de goiabeira serrana: SCS 411 Alcântara e SCS 412 Helena. Agropecuária Catarinense, v.20, n.2, p.77-80, 2007.

Fantinel, V.S. Caracterização do patossistema Colletotrichum spp./ goiabeira-serrana. Santa Maria: Universidade Federal de Santa Maria, 2020. 157p. Tese Doutorado.
Fantinel, V.S.; Muniz, M.F.B.; Blume, E.; Araújo, M.M.; Poletto, T., Da Silva, T.T.; Harakava, R. First report of Colletotrichum siamense causing anthracnose on Acca sellowiana fruits in Brazil. Plant Disease, v.101, n.6, p.1035, 2017. https://doi.org/10.1094/PDIS01-17-0096-PDN.

Ferreira, D.F. Sisvar: a computer statistical analysis system. Ciência e Agrotecnologia, v. 35, n.6, p.1039-1042, 2011. https://doi. org/10.1590/S1413-70542011000600001.

Hellwig, T.; Ueno, B. Levantamento de fitopatógenos causadores de doenças em frutíferas nativas na região sul do Rio Grande do Sul. Revista Brasileira de Agroecologia, v.4, n.2, p.15601564, 2009. http://revistas.aba-agroecologia.org.br/index.php/ rbagroecologia/article/view/8325. 20 Jan. 2020.

Ishikawa, M.S.; Ribeiro, N.R.; Oliveira, E.C.; Almeida, A.A.; Balbi-Peña, M.I. Screening of soybean cultivars resistant to black root rot (Macrophomina phaseolina). Summa Phytopathologica, v.44, n.1, p.38-44, 2018. https://doi.org/10.1590/0100-5405/178653.

Lardner, R.; Johnston, P.R.; Plummer, K.M.; Pearson, M.N. Morphological and molecular analysis of Colletotrichum acutatum sensu lato. Mycological Research, v.103, n.3, p.275285, 1999. https://doi.org/10.1017/S0953756298007023.

Lopes, M.E. Caracterização morfológica de isolados de Colletotrichum sp., agente causal da antracnose em goiabeira-serrana (Acca sellowiana) (O. Berg.) Burret. Florianópolis: Universidade Federal de Santa Catarina, 2013. 111p. Dissertação Mestrado. https:// repositorio.ufsc.br/handle/123456789/122836. 10 Jan. 2020.

Mosquera, D.J.; Alves, E.; Ciotta, M.N.; Freitas, D.C.L.; Amarante, C.; Marques, L.D.L. Incidência e severidade de antracnose em diferentes genótipos de goiabeira-serrana. Agropecuária Catarinense, v.31, suplemento, p.184, 2018. https://senafrut. com.br/assets/uploads/Resumos.pdf. 22 Jan. 2020.

Singh, A.K.; Singh, P.K.; Arya, M.; Singh, N.K.; Singh, U.S. Molecular screening of blast resistance genes in rice using SSR markers. Plant Pathology Journal, v.31, n.1, p.12-24, 2015. https://doi. org/10.5423/PPJ.OA.06.2014.0054.

Wagner, M.A.; Fiaschi, P. Myrtaceae from the Atlantic forest subtropical highlands of São Joaquim National Park (Santa Catarina, Brazil). Rodriguésia, v.71, e04032017, 2020. https://doi. org/10.1590/2175-7860202071006.

Walker, C.; Muniz, M.F.B.; Martins, R.O.; Rabuske, J.E.; Santos, A.F. Susceptibility of pecan cultivars to Cladosporium cladosporioides species complex. Floresta e Ambiente, v. 25, n. 4, e20170267, 2018. https://doi.org/10.1590/2179-8087.026717. 